\title{
Dual-Layer Corrosion-Resistant Conversion Coatings on Mg-9Li Alloy via Hydrothermal Synthesis in Deionized Water
}

\author{
Dan Song ${ }^{1,2, *}$, Beibei Lian ${ }^{1}$, Yulong Fu ${ }^{1}$, Guowei Wang ${ }^{1, *}$, Yanxin Qiao ${ }^{3 \oplus}$, Eyram Edwin Klu ${ }^{1}$, Xinyue Gong ${ }^{1}$ \\ and Jinghua Jiang ${ }^{1, *}$
}

1 College of Mechanics and Materials, Hohai University, Nanjing 211100, China; jybblbb@163.com (B.L.); 15770568271@163.com (Y.F.); kluedwin@outlook.com (E.E.K.); gongxinyuezd@163.com (X.G.)

2 Suqian Research Institute, Hohai University, Suqian 223800, China

3 School of Materials Science and Engineering, Jiangsu University of Science and Technology, Zhenjiang 212003, China; yxqiao@just.edu.cn

* Correspondence: songdancharls@hhu.edu.cn (D.S.); guowei_wang9606@163.com (G.W.); jinghua-jiang@hhu.edu.cn (J.J.); Tel.: +86-25-8378-7239 (D.S.); Fax: +86-25-8378-6046 (D.S.)

Citation: Song, D.; Lian, B.; Fu, Y.; Wang, G.; Qiao, Y.; Klu, E.E.; Gong, X.; Jiang, J. Dual-Layer

Corrosion-Resistant Conversion Coatings on Mg-9Li Alloy via Hydrothermal Synthesis in Deionized Water. Metals 2021, 11, 1396. https:// doi.org/10.3390/met11091396

Academic Editor: Frank Czerwinski

Received: 3 August 2021

Accepted: 30 August 2021

Published: 3 September 2021

Publisher's Note: MDPI stays neutral with regard to jurisdictional claims in published maps and institutional affiliations.

Copyright: (c) 2021 by the authors. Licensee MDPI, Basel, Switzerland. This article is an open access article distributed under the terms and conditions of the Creative Commons Attribution (CC BY) license (https:// creativecommons.org/licenses/by/ $4.0 /)$.

\begin{abstract}
The formation of a corrosion-resistant coating by the hydrothermal method is an effective way to provide significant protection to magnesium alloys. However, it is a challenge to prepare such a coating on magnesium-lithium alloys because of its high chemical activity. Herein, the dual-layer structured corrosion-resistant conversion coating composed with $\mathrm{Mg}(\mathrm{OH})_{2}$ and $\mathrm{LiOH}$ was successfully synthesized on $\mathrm{Mg}-9 \mathrm{Li}$ alloy by the optimization of the hydrothermal reaction in deionized water. The coating synthesized at $140{ }^{\circ} \mathrm{C}$ for $2 \mathrm{~h}$ has the best anti-corrosion performance in all obtained coatings, which has a uniform and compact coating with thickness of about $3 \mu \mathrm{m}$. The improvement of the hydrophobicity due to the stacking structure of the surface layer, as well as the barrier effect of its inner compact coating on corrosive media, lead to the excellent anti-corrosion performance of the obtained hydrothermal conversion coating
\end{abstract}

Keywords: Mg-9Li alloy; hydrothermal conversion coating; anti-corrosion performance; coating microstructure

\section{Introduction}

As it is well known, Mg-Li alloys have attracted great interest in the fields of aerospace, military and $3 \mathrm{C}$ industries because of their promising properties such as high specific modulus, low density, excellent formability and electromagnetic shielding [1-6]. Meanwhile, the phase structure and mechanical properties of $\mathrm{Mg}$-Li alloys will change with the difference of lithium content. When lithium content is less than $5.7 \mathrm{wt} \%$, the alloy is composed of $\alpha-\mathrm{Mg}$ phase with hexagonal close-packed (hcp) structure. The alloy with lithium content higher than $10.3 \mathrm{wt} . \%$ is composed of $\beta$-Li phase with body-centered cubic (bcc) structure. When lithium content is higher than $5.7 \mathrm{wt} \%$ and lower than $10.3 \mathrm{wt} . \%$, the alloy is composed of $\alpha-\mathrm{Mg}$ and $\beta$-Li duplex phase structure [7-9]. However, low corrosion resistance and an excessively fast corrosion rate are major obstacles for the wide spread use of $\mathrm{Mg}-\mathrm{Li}$ alloys due to the higher chemical activity of lithium compared to magnesium. Meanwhile, for the dual-phase Mg-Li alloy, the microscale galvanic cells between the Mg-riched phase and Li-riched phase will further accelerate the corrosion rate of the alloy [10-13]. Thus, it is of great practical significance to improve the corrosion resistance of $\mathrm{Mg}-\mathrm{Li}$ alloys.

Formation of an anti-corrosion coating on the surface is an effective way to reduce the corrosion rate of $\mathrm{Mg}$-Li alloys [14]. The coating serves as a barrier between the $\mathrm{Mg}-\mathrm{Li}$ alloy matrix and the external environment, inhibiting the transmission of corrosive media to the matrix. So far, a variety of $\mathrm{Mg}$ - Li alloys coating technologies have been reported, including anodic oxide coating [15,16], vapor deposition coating [17], chemical conversion coating [18-21], organic coating [22], and plasma spraying coating [23]. Among these 
methods, either complicated operations and equipment or large poison-containing chemical reagents are needed. Hence, a facile, low cost, environmentally friendly and rapid method is required to overcome this issue.

In recent years, the hydrothermal synthesis technique has been one of the most promising potential methods to achieve in-situ synthesis of an anti-corrosion coating on alloy surfaces. The principle of the hydrothermal method is to place the metal substrate in a high-temperature and -pressure reactor to react with the precursor solution, thereby forming a crystalline coating on the surface of the substrate. For magnesium alloys, heating and insulating the reactor below $200{ }^{\circ} \mathrm{C}$ can obtain a stable coating [24]. Many studies have showed that this kind of approach is one of the most promising emerging ways to protect magnesium alloys from corrosion. Guo et al. [25] deposited a protective coating on the Mg-2Zn-0.5Mn-Ca-Ce alloy via the hydrothermal method. They studied the effect of synthesizing temperature on microstructure and electrochemical property of the coatings. Zhu et al. [26] fabricated protective coatings on AZ31 magnesium alloy by the hydrothermal method with deionized water as a precursor solution, and results showed that coatings can improve the corrosion resistance of alloys effectively, and the thickness of the coating increased with the hydrothermal temperature and time. Gupta et al. [27] developed a compact and well-adherent $\mathrm{Mg}(\mathrm{OH})_{2}$ layer by the hydrothermal technique, which improved the corrosion performance of the $\mathrm{Mg}$ substrate in phosphate buffer saline (PBS) solution. Feng et al. [28] proposed a one-step hydrothermal method to fabricate a super-hydrophobic surface on AZ91 magnesium alloy to enhance corrosion resistance and anti-bacteria adhesion. The as-obtained coatings prepared by this technique usually are uniform, compact, and have strong adhesion to substrates and thus can effectively inhibit the direct contact between the corrosive media and substrates. Meanwhile, the use of water as the only or main chemical during the hydrothermal treatment is more environmentally friendly, which also makes the coating more stable as the substrate is involved in the reaction [29]. However, there are almost no reports on the application of the hydrothermal method to Mg-Li based alloys because of their high chemical activity, which brings high risk of dissolution of the alloy during the hydrothermal synthesizing processing via high temperature and pressure. Therefore, the preparation of a coating on the surface of $\mathrm{Mg}-\mathrm{Li}$ alloys by the hydrothermal method has many challenges.

In this paper, we propose a hydrothermal method with deionized water as precursor solution to develop the corrosion-resistant coating on a highly active magnesium-lithium alloy. The effects of hydrothermal temperature on the microstructure, thickness and anticorrosion performance of the conversion coating were systematically studied. The results indicate that this simple method without any environmental toxicity can effectively enhance the anti-corrosion performance of magnesium-lithium alloys, and is thought applicable to other light alloys.

\section{Experimental}

\subsection{Synthesizing Process of Hydrothermal Conversion Coating}

The material to be processed was cut from a cast Mg-9Li alloy ingot, of which the chemical composition was detected by inductively coupled plasma optical emission spectrometry (ICP-OES) (Iris Advantage 1000, NY, USA) and listed in Table 1. The Mg-9Li alloy was cut into square samples with thickness of $2 \mathrm{~mm}$ and widths of $10 \mathrm{~mm}$. Each sample was gradually ground with silicon carbide sandpapers successively up to \# 1500 grit, followed by mechanical polishing to a mirror-like finish, which was carried out using polishing fluid with $0.05 \mu \mathrm{m} \mathrm{Al} \mathrm{O}_{3}$ polishing powder at the speed of $500 \mathrm{r} / \mathrm{min}$. Finally, ultrasonic cleaning was performed in deionized water and acetone for $5 \mathrm{~min}$ each, and then each sample was dried in air. 
Table 1. Chemical composition of Mg-9Li alloy (wt.\%).

\begin{tabular}{ccccccccc}
\hline Element. & $\mathbf{M g}$ & $\mathbf{L i}$ & $\mathbf{F e}$ & $\mathbf{M n}$ & $\mathbf{Z n}$ & $\mathbf{C d}$ & $\mathbf{C u}$ & $\mathbf{N i}$ \\
\hline Wt.\% & 91.061 & 8.812 & 0.010 & 0.022 & 0.013 & 0.030 & 0.002 & 0.003 \\
\hline
\end{tabular}

In this study, the deionized water was poured into a Teflon-lined stainless-steel autoclave with a capacity of $100 \mathrm{~mL}$, which was filled to $70 \%$ of its capacity. Three parallel samples were immersed in precursor solution, and hydrothermal-synthesizing processed in the autoclave via an electric furnace for $2 \mathrm{~h}$ with different heating temperatures of 120, 130, 140 and $150{ }^{\circ} \mathrm{C}$. After that, the samples were taken out and then dried in air. For simplicity, the coated samples are named as the $120^{\circ} \mathrm{C}$-coated sample, $130{ }^{\circ} \mathrm{C}$-coated sample, $140{ }^{\circ} \mathrm{C}$-coated sample and $150{ }^{\circ} \mathrm{C}$-coated sample, in order.

\subsection{Microstructure Characterizations}

The macro-morphologies of the coatings were observed by a Stereo microscope (KH-7700, Hamburg, NY, USA). The images of surface and cross-sectional micro-morphologies of the coated samples, as well as the microstructure of the cast Mg-9Li alloy, were obtained using a scanning electron microscope (SEM, EM-30AX, Yongin, Korea) at an accelerating voltage of $15 \mathrm{kV}$. All the samples were sputtered with gold before observation. The phase structures of the substrate and coated samples were characterized by X-ray diffraction (XRD, Smartlab $9 \mathrm{kw}$, Tokyo, Japan) technique with $\mathrm{Cu} \mathrm{K} \alpha$ radiation, and the scanning rate was maintained at $2^{\circ} / \mathrm{min}$.

\subsection{Performance Evaluation}

The surface wettability of the substrate and coated samples was measured with a $5 \mu \mathrm{L}$ droplet using an optical contact angle measuring instrument (SDC-350, Wenzhou, China). The measurement of contact angle is static, and the sample stage is placed at an angle of $180^{\circ}$. The magnified image of the liquid phase and solid phase contact surface was presented in the software when the sample was placed in the instrument for measurement. Then, the software's measurement angle program automatically identified contact point and fitted the contact angle using the maxima of local slopes in the left and right sides of the droplet. In order to obtain accurate results, five measurements were made for each contact angle of each sample, and then the average values were used.

The scratch test/tape test was used to evaluate the bonding strength between conversion coating and substrate according to ASTM D3359-02 method B [30]. Firstly, cross-hatch lines at angles of $90^{\circ}$ were cut on the coating, making the cutting edge reach the substrate. Then, 3M tape was attached firmly to the cut surface and removed after $2 \mathrm{~min}$. Finally, the remaining coating was observed with SEM and assessed by comparison with descriptive illustrations in ASTM standard (Classified from 0B to 5B).

Electrochemical corrosion tests with reference to EIS-ASTM G106 and PP-ASTM G5 were performed in $0.1 \mathrm{~mol} / \mathrm{L} \mathrm{NaCl}$ solution using CHI660E (Chenhua, Shanghai, China) electrochemical workstation with a standard three-electrode configuration. A saturated calomel electrode and platinum stick electrode were used as the reference electrode and counter electrode, respectively, while the tested samples were used as the working electrode. All coated samples including the substrate were inlaid with epoxy resin with a squared exposure coating of $1 \mathrm{~cm}^{2}$, while the back face was connected by a copper wire. Two electrochemical measurements were systematically conducted, including electrochemical impedance spectroscopy (EIS) and potentiodynamic polarization (PP). The system is open to air at all stages, and before the PP and EIS tests, the samples were pre-immersed in the solution for $1 \mathrm{~h}$ to reach the stable open circuit potential (OCP). EIS study was performed in the frequency range from $100 \mathrm{kHz}$ to $0.01 \mathrm{~Hz}$, accompanied by $5 \mathrm{mV}$ amplitude of sinusoidal potential. EIS experimental data were fitted and analyzed using ZSimpWin software. PP measurement was conducted at a scan rate of $1 \mathrm{mV} \cdot \mathrm{s}^{-1}$ in the applied 
potential range of $\pm 250 \mathrm{mV}$ vs. the OCP. To ensure good reproducibility, at least three parallel samples were tested in all electrochemical tests.

The corrosion behavior and corrosion rate of the substrate and coated samples were studied via hydrogen evolution immersion test in $0.1 \mathrm{~mol} / \mathrm{L} \mathrm{NaCl}$ solution at the ambient temperature $25 \pm 2{ }^{\circ} \mathrm{C}$. Three parallel samples were molded in the epoxy with a squared exposure coating of $3 \mathrm{~cm}^{2}$. Hydrogen gas released from the corrosion process was collected in the self-made equipment (a beaker connected to an inverted funnel and a burette), and evolved hydrogen was recorded at specified intervals. All tests were made in triplicate. The macroscopic and microscopic morphologies of the corroded samples were observed by a Stereo microscope and SEM, respectively.

\section{Results and Discussion}

\subsection{Microstructure Characteristic}

Figure 1 shows the SEM microstructure of the substrate Mg-9Li alloy. It is apparent that the Mg-9Li alloy exhibits a typical dual-phase structure, which includes the bright lath phase and dark matrix phase. It is well known that the bright lath phase is the Mg-enriched $\alpha$ phase with hcp structure, which is a solution of lithium in magnesium and usually named as $\alpha-\mathrm{Mg}$ phase [31]. The dark matrix phase surrounding the $\alpha-\mathrm{Mg}$ phase is briefly named as $\beta$-Li phase, which is a solution of magnesium in lithium and shows a bcc structure [32]. It can be seen from the figure that the volume fraction of $\beta$-Li phase is larger than that of the $\alpha-\mathrm{Mg}$ phase, which is because the atomic ratio of lithium to magnesium is much higher than $9 \%$, resulting in large-scale changes in the lithium content in the two phases.

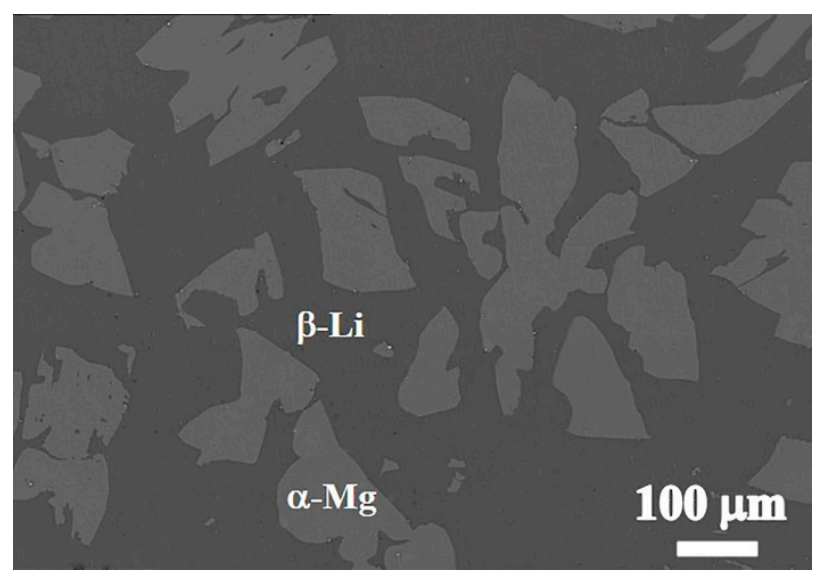

Figure 1. SEM microstructure of the Mg-9Li alloy.

The optical macroscopic and SEM microscopic morphologies of the coatings as a function of the hydrothermal synthesizing temperature are shown in Figure 2. As seen from the optical micrographs, their appearance shows clear contrasts in optical observations. The color of the coatings appears more uniform and grayish brown as the hydrothermal synthesized temperature increases from 120 to $140{ }^{\circ} \mathrm{C}$, which is accompanied by the appearance of phase features of the substrate alloy. However, when the hydrothermal temperature rises to $150^{\circ} \mathrm{C}$, the coating changes significantly, which is mainly manifested in the color of the coating turning white and partially powdery. Meanwhile, as evident from SEM images (Figure 2a,b), all coating surfaces are covered with nano-scale microstructures, which are identified as the stacking structure of the hexagonal flake $\mathrm{Mg}(\mathrm{OH})_{2}$ crystal units [27], and the hexagonal structure of $\mathrm{Mg}(\mathrm{OH})_{2}$ is more clearly evident in the $140^{\circ} \mathrm{C}$-coated sample (Figure 2c). However, as the hydrothermal reaction temperature rises to $150^{\circ} \mathrm{C}$, the coating is severely damaged, which echoes the observation of macro surface-morphologies. 
(a)

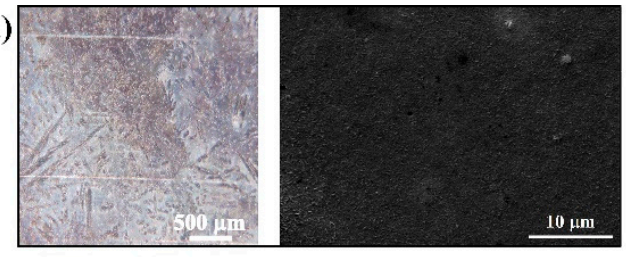

(c)

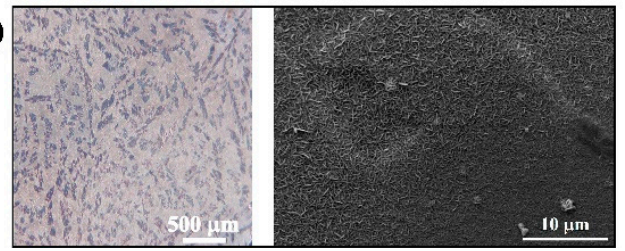

(b)

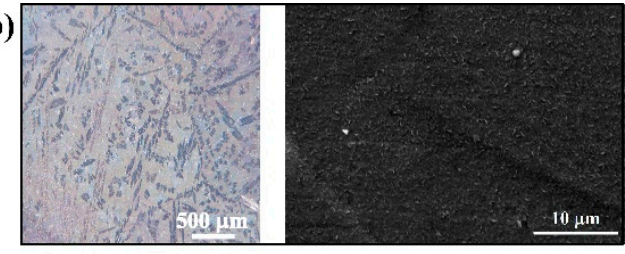

(d)

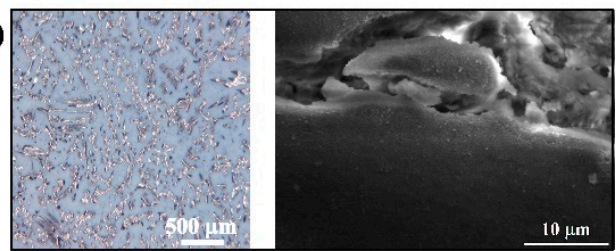

Figure 2. Macroscopic morphologies of surfaces and the corresponding microscopic morphologies of the (a) $120^{\circ} \mathrm{C}$-coated sample; (b) $130{ }^{\circ} \mathrm{C}$-coated sample; (c) $140{ }^{\circ} \mathrm{C}$-coated sample; and (d) $150{ }^{\circ} \mathrm{C}$-coated sample.

The XRD analysis was carried out to detect the phase structures of the substrate alloy and coatings. Figure 3 shows the XRD patterns of the substrate and coated samples. As marked in the patterns, besides $\beta$-Li phase and strong $\alpha-\mathrm{Mg}$ phase peaks in the untreated sample, other new diffraction peaks appear in the hydrothermally treated samples. They correspond to the hydrothermal products, $\mathrm{Mg}(\mathrm{OH})_{2}$ and $\mathrm{LiOH}$, which also confirms the presence of hexagonal structure of $\mathrm{Mg}(\mathrm{OH})_{2}$ in the SEM images. The formation of $\mathrm{Mg}(\mathrm{OH})_{2}$ and $\mathrm{LiOH}$ on the surface of $\mathrm{Mg}-9 \mathrm{Li}$ alloy during the hydrothermal synthesizing reaction using deionized water can be inferred as following reactions:

$$
\begin{gathered}
\mathrm{H}_{2} \mathrm{O} \rightarrow \mathrm{H}^{+}+\mathrm{OH}^{-} \\
\mathrm{Mg}+2 \mathrm{H}^{+} \rightarrow \mathrm{Mg}^{2+}+\mathrm{H}_{2} \\
2 \mathrm{Li}+2 \mathrm{H}^{+} \rightarrow 2 \mathrm{Li}^{+}+\mathrm{H}_{2} \\
\mathrm{Mg}^{2+}+2 \mathrm{OH}^{-} \rightarrow \mathrm{Mg}(\mathrm{OH})_{2} \\
\mathrm{Li}^{+}+\mathrm{OH}^{-} \rightarrow \mathrm{LiOH}
\end{gathered}
$$

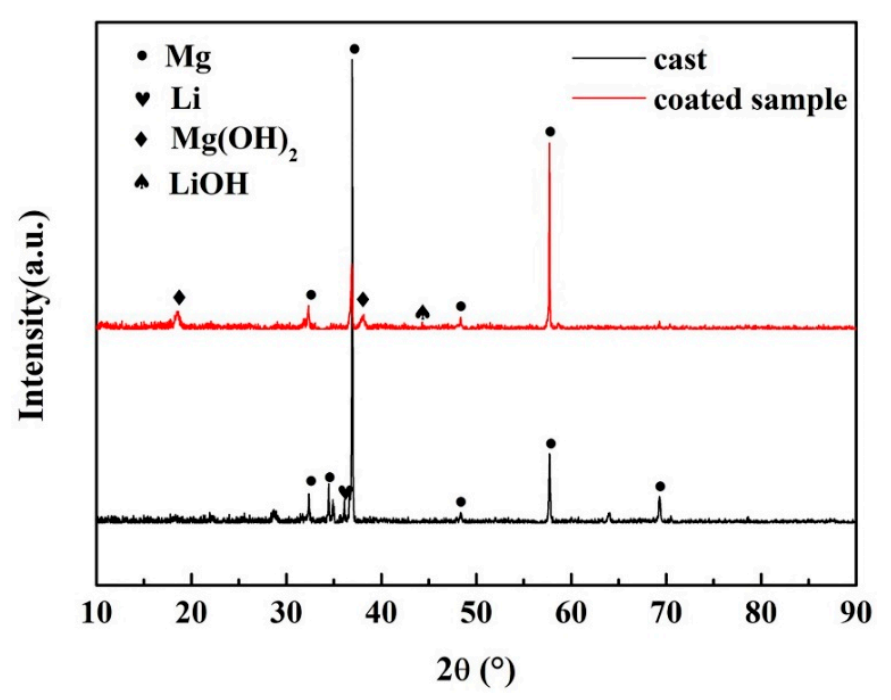

Figure 3. XRD patterns of the substrate and coated sample.

Therefore, one can judge that the hydrothermal conversion coating is mainly composed of $\mathrm{Mg}(\mathrm{OH})_{2}$ and $\mathrm{LiOH}$.

The cross-sectional SEM morphologies of the coated samples were conducted to study the influence of hydrothermal temperature on the microstructure characteristic and thick- 
ness of the conversion coatings. As shown in Figure 4, it is evident that the thickness of the coating increases with an increase in the hydrothermal synthesizing temperature. The thicknesses of the coatings prepared at 120 and $130^{\circ} \mathrm{C}$ are approximately $1.2 \pm 0.08 \mu \mathrm{m}$ and $1.5 \pm 0.06 \mu \mathrm{m}$, respectively, as shown in Figure $4 \mathrm{a}, \mathrm{b}$. When the hydrothermal synthesizing temperature is elevated to $140^{\circ} \mathrm{C}$, the coating thickness exhibits better uniformity and compactness than the other three kinds of samples, which has thicker coating about $3.2 \pm 0.02 \mu \mathrm{m}$ (Figure 4c). It can be seen from Figure $4 \mathrm{~d}$ that the growth of the coating shows a faster rate at $150{ }^{\circ} \mathrm{C}$, and the thickness reaches about $9.2 \pm 0.49 \mu \mathrm{m}$. However, the uniformity and compactness of the coating become worse, and the cross section is irregularly distributed with many internal cracks. The increase in the thickness with increasing hydrothermal temperature can be explained by the effect of high-temperature and high-pressure on ionization of water. According to the Arrhenius equation, this increased degree of ionization improves the reaction rate between $\mathrm{Mg}-9 \mathrm{Li}$ alloy and deionized water $[26,33]$. However, the water vapor pressure as well as the activity of water increases significantly when the temperature is $150^{\circ} \mathrm{C}$, which provides a driving force for the water to penetrate the coating [34]. Thus, it is presumed that obvious cracks inside the layer and loose structure are caused by the possibly higher internal stress under an elevated reaction temperature. Therefore, the formation of a compact and uniform coating requires a suitable hydrothermal reaction temperature.
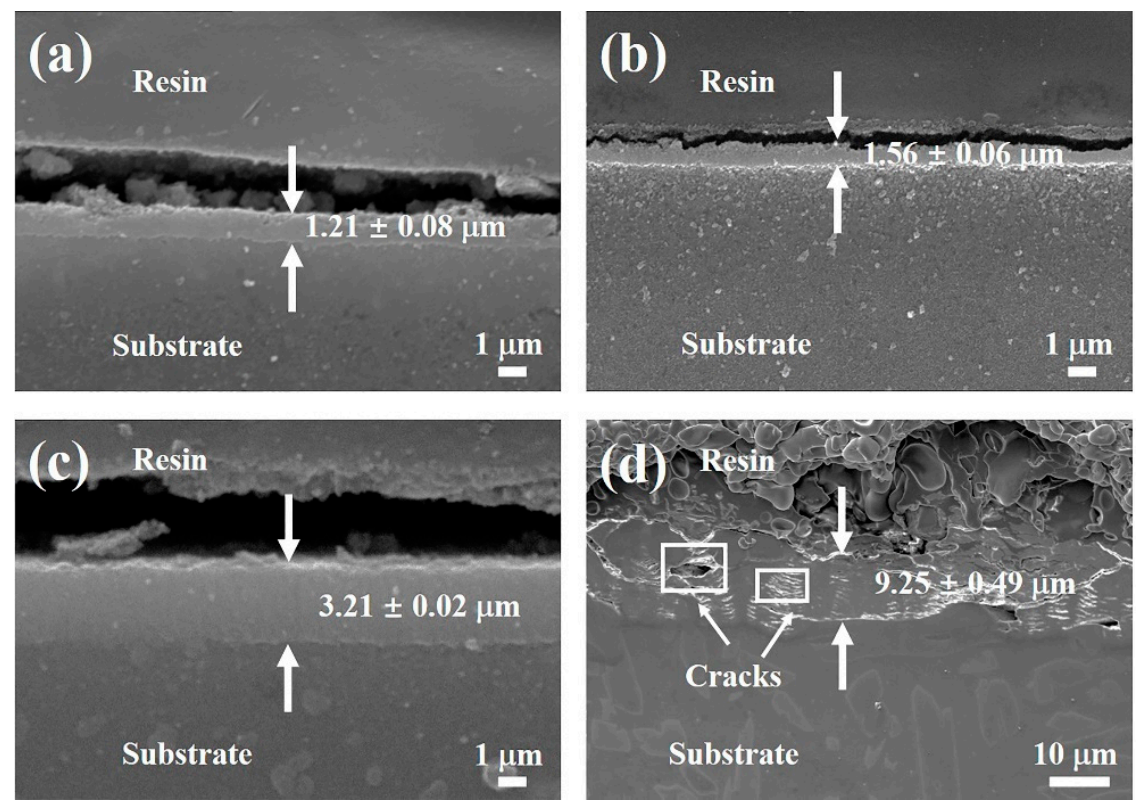

Figure 4. Cross-sectional morphologies of the coated samples: (a) $120^{\circ} \mathrm{C}$-coated sample; (b) $130{ }^{\circ} \mathrm{C}$-coated sample; (c) $140{ }^{\circ} \mathrm{C}$-coated sample; (d) $150{ }^{\circ} \mathrm{C}$-coated sample.

\subsection{Anti-Corrosion Performance}

The electrochemical corrosion resistance of the as-cast and hydrothermally coated $\mathrm{Mg}-9 \mathrm{Li}$ alloys in $\mathrm{NaCl}$ solution was studied using electrochemical testing. Figure 5a-c present the Nyquist and Bode plots for the uncoated and hydrothermally coated samples. As seen in Figure 5a, the Nyquist plots of the uncoated and hydrothermally coated samples are composed of two capacitive arcs and one inductive arc. The two capacitive arcs correspond to the EIS signals of the substrate and the coating, which are also typical Nyquist characteristics of many coated samples [35,36]. Meanwhile, the appearance of inductive arc confirms the initiation and propagation of corrosion, indicating that all samples have been corroded to some extent. As generally believed, the larger the capacitive arc diameter, the better the corrosion resistance [37]. It can be clearly seen from Figure 5a that the diameter of all coated sample is much larger than that of the $\mathrm{Mg}-9 \mathrm{Li}$ substrate 
alloy. Among all coated samples, the $140{ }^{\circ} \mathrm{C}$ synthesized one has the largest capacitive, indicating the best corrosion resistance and anti-corrosion performance of its coating.
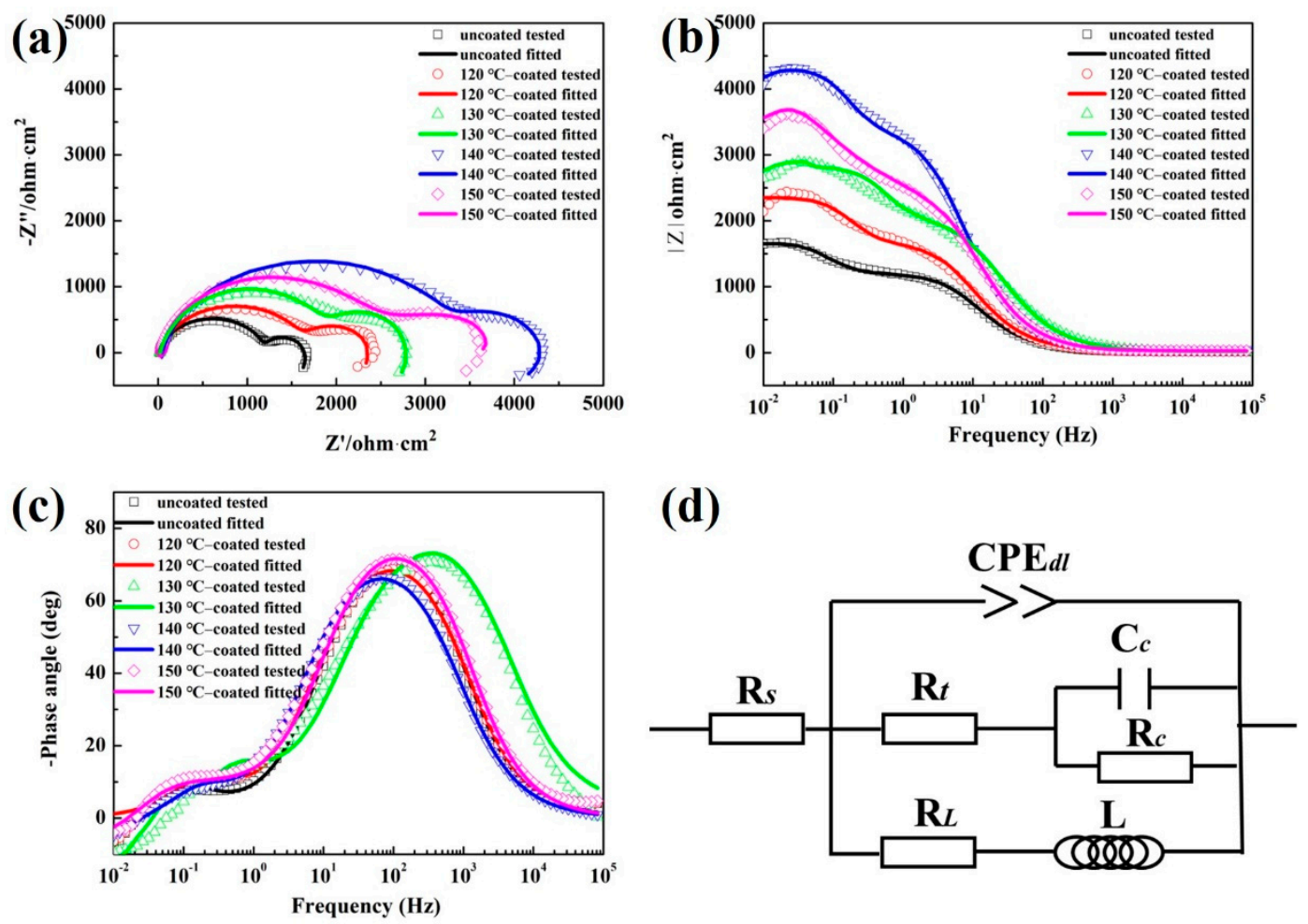

Figure 5. Nyquist (a) and Bode $(\mathbf{b}, \mathbf{c})$ plots for the substrate and coated samples. (d) Equivalent electrical circuits.

Furthermore, the $|Z|$ values of coated samples are much higher than that of the uncoated Mg-9Li sample according to the Bode impedance plots (Figure 5b). The result clearly shows that the hydrothermal conversion coatings provide corrosion prevention to the substrate $\mathrm{Mg}$-9 $\mathrm{Li}$ alloy. The sample prepared at $140{ }^{\circ} \mathrm{C}$ exhibits the largest $|\mathrm{Z}|$, which further confirms the excellent corrosion protective nature and coincides well with the Nyquist results. The substrate and coated samples present two-time constants within the frequency range, reflecting the responses of outer porous layer and inner barrier layer (Figure 5c).

The equivalent circuit is used to further fit and analyze the corrosion process of samples in $\mathrm{NaCl}$ solution. As shown in Figure $5 \mathrm{~d}$, the equivalent circuit $R_{\mathrm{S}}\left(C P E_{\mathrm{dl}}\left(R_{\mathrm{t}}\left(R_{\mathrm{c}} C_{\mathrm{c}}\right)\left(R_{\mathrm{L}} L\right)\right)\right)$ was used to simulate the tested EIS plots of the substrate and coated samples, and the EIS fitting parameters are listed in Table 2. In this model, $R_{S}$ represents the resistance of the electrolyte solution. The high-frequency capacitance loop was mainly related to outer layer properties, which corresponded to electrical components of $R_{\mathrm{ct}}$ and $C P E_{\mathrm{dl}}$. The constant phase element $\left(C P E_{\mathrm{dl}}\right)$, representing double layer capacitance and being expressed as $\mathrm{Y}_{0}$ and $\mathrm{n}$, is used to improve the fitting quality instead of the ideal capacitance [38]. $\mathrm{n}$ is usually between 0.5 and 1 in the corrosion system of magnesium alloys $[39,40]$. $R_{\mathrm{t}}$ represents the charge transfer resistance and can be used to evaluate the corrosion resistance of the sample [41]. The larger the $R_{\mathrm{t}}$ value, the more sluggish the corrosion process [42]. As seen in Table 2, the $140{ }^{\circ} \mathrm{C}$-coated sample shows the largest $R_{\mathrm{t}}$ value $\left(3410 \Omega \cdot \mathrm{cm}^{2}\right)$, indicating that $140{ }^{\circ} \mathrm{C}$ is the optimal parameter for improving corrosion resistance on a Mg-9Li alloy substrate. $R_{\mathrm{c}}$ and $C_{\mathrm{c}}$ characterize the media capacitance loop, which is originated from the diffusion through a porous solid film on the alloy surface [43-45]. Thus, for the substrate and coated samples, $C_{\mathrm{c}}$ refers to a constant phase element capacitance of the newly formed layer $\left(\mathrm{Mg}(\mathrm{OH})_{2}\right.$ and $\mathrm{LiOH}$ corrosion products) and hydrothermal conversion coating, respectively. $R_{\mathrm{c}}$ represents the diffusion resistance of the electrolyte through these two layers, respectively. $R_{\mathrm{L}}$ and $L$ represent the inductive loop, which attribute to the corrosion 
nucleation at the initiation stage of localized corrosion, and can be described as the pitting corrosion of the newly formed layer and hydrothermal conversion coating [46].

Table 2. Fitted EIS parameters for the substrate and coated samples in $\mathrm{NaCl}$ solution based on the equivalent circuit models.

\begin{tabular}{|c|c|c|c|c|c|c|}
\hline Sample & $R_{\mathrm{s}}\left(\Omega \cdot \mathrm{cm}^{2}\right)$ & $R_{\mathrm{c}}\left(\Omega \cdot \mathrm{cm}^{2}\right)$ & $R_{\mathrm{t}}\left(\Omega \cdot \mathrm{cm}^{2}\right)$ & $C_{\mathrm{c}}\left(\mathrm{F} \cdot \mathrm{cm}^{-2}\right)$ & $\begin{array}{c}C P E_{\mathrm{dl}} \\
\mathrm{Y}_{0}\left(\mathrm{~S} \cdot \mathrm{sn} \cdot \mathrm{cm}^{-2}\right)\end{array}$ & $\mathbf{n}$ \\
\hline uncoated & $14.92 \pm 2.3$ & $457.6 \pm 1.3$ & $1196 \pm 1.1$ & $4.398 \pm 1.3 \times 10^{-3}$ & $2.279 \pm 0.2 \times 10^{-5}$ & $0.9052 \pm 0.1$ \\
\hline $120^{\circ} \mathrm{C}$-coated & $18.96 \pm 2.5$ & $658.6 \pm 1.5$ & $1679 \pm 0.3$ & $1.838 \pm 1.7 \times 10^{-3}$ & $1.975 \pm 0.2 \times 10^{-5}$ & $0.8879 \pm 0.6$ \\
\hline $130^{\circ} \mathrm{C}$-coated & $27.86 \pm 3.3$ & $718.7 \pm 1.0$ & $2094 \pm 0.8$ & $1.564 \pm 0.8 \times 10^{-3}$ & $4.258 \pm 0.7 \times 10^{-5}$ & $0.8418 \pm 1.1$ \\
\hline $140^{\circ} \mathrm{C}$-coated & $41.78 \pm 1.7$ & $885.6 \pm 0.8$ & $3410 \pm 0.1$ & $1.141 \pm 1.0 \times 10^{-3}$ & $1.393 \pm 0.4 \times 10^{-5}$ & $0.8676 \pm 0.4$ \\
\hline $150^{\circ} \mathrm{C}$-coated & $28.11 \pm 4.1$ & $776.3 \pm 1.6$ & $2565 \pm 0.7$ & $1.491 \pm 1.2 \times 10^{-3}$ & $1.098 \pm 0.3 \times 10^{-5}$ & $0.8982 \pm 1.3$ \\
\hline
\end{tabular}

The potentiodynamic polarization (PP) is widely conducted to study the anti-corrosion performance of samples under strong polarization, and the PP curves of the substrate and coated samples are shown in Figure 6. Meanwhile, the corrosion potential $\left(E_{\text {corr }}\right)$ and corrosion current density $\left(I_{c o r r}\right)$ for various samples obtained according to the Tafel extrapolation method are listed in Table 3. It can be seen that coated samples have obviously more noble $E_{\text {corr }}$ values than that of the substrate, and the $140{ }^{\circ} \mathrm{C}$-coated sample has the noblest $\left.E_{\text {corr }}-1.471 \mathrm{~V}\right)$. On the other hand, compared with the substrate, the corrosion current density of 130, 140 and $150^{\circ} \mathrm{C}$ coated samples decreased by an order of magnitude. Among them, the $I_{\text {corr }}$ value of $140^{\circ} \mathrm{C}$-coated sample is the smallest, reaching $7.013 \times 10^{-6} \mathrm{~A} \cdot \mathrm{cm}^{-2}$. As known, the higher $E_{\text {corr }}$ and lower $I_{\text {corr }}$ usually indicate that the sample has better corrosion resistance [47-49]. In addition to $I_{c o r r}$ and $E_{c o r r}$, it can also be found that the anodic polarization rate $\left(\beta_{\alpha}\right)$ of the coated samples is larger than that of the uncoated sample, and this phenomenon is more obvious in the $140{ }^{\circ} \mathrm{C}$-coated sample. The larger the anodic polarization rate, the smaller the anodic corrosion kinetics, indicating that the coating has a better protective effect on the penetration of corrosive media into the substrate/coating interface. Therefore, the hydrothermally formed conversion coating prepared at $140{ }^{\circ} \mathrm{C}$ has better protective performance.

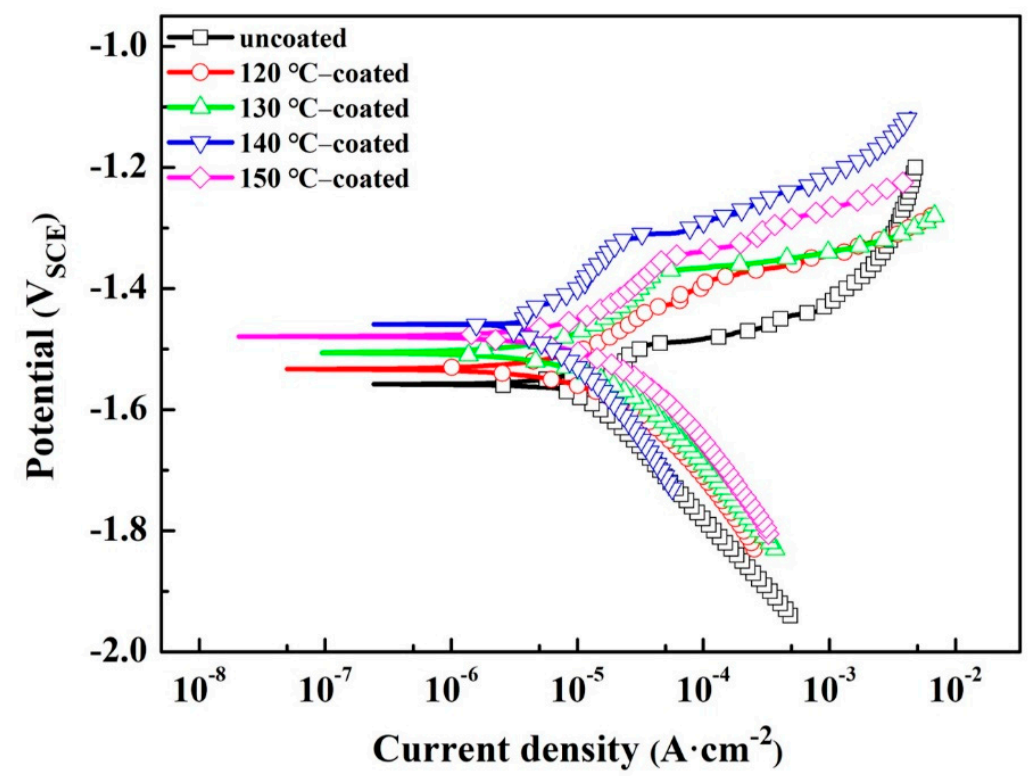

Figure 6. Polarization curves of the substrate and coated samples immersed in $\mathrm{NaCl}$ solution. 
Table 3. Electrochemical parameters of the substrate and the coated samples via the potentiodynamic polarization (PP) curves.

\begin{tabular}{ccc}
\hline Samples & $\boldsymbol{E}_{\text {corr }} \mathbf{( V )}$ & $\boldsymbol{I}_{\text {corr }} \mathbf{( A \cdot \mathbf { c m } ^ { - \mathbf { 2 } } )}$ \\
\hline uncoated & $-1.558 \pm 0.02$ & $1.167 \pm 0.04 \times 10^{-5}$ \\
$120^{\circ} \mathrm{C}$-coated & $-1.531 \pm 0.05$ & $1.033 \pm 0.02 \times 10^{-5}$ \\
$130{ }^{\circ} \mathrm{C}$-coated & $-1.505 \pm 0.01$ & $9.337 \pm 0.03 \times 10^{-6}$ \\
$140^{\circ} \mathrm{C}$-coated & $-1.471 \pm 0.02$ & $7.013 \pm 0.01 \times 10^{-6}$ \\
$150{ }^{\circ} \mathrm{C}$-coated & $-1.489 \pm 0.03$ & $8.264 \pm 0.02 \times 10^{-6}$ \\
\hline
\end{tabular}

A hydrogen evolution immersion test was conducted to reveal the long-term anticorrosion performance of the hydrothermally coated samples in $0.1 \mathrm{~mol} / \mathrm{L} \mathrm{NaCl}$ solution for 6 days, and the obtained hydrogen-evolution curves of the substrate and coated samples were presented in Figure 7. In all stages of corrosion, the hydrogen evolution volume can be arranged in descending order as follows: cast $>120^{\circ} \mathrm{C}$-coated sample $>130{ }^{\circ} \mathrm{C}$-coated sample $>150{ }^{\circ} \mathrm{C}$-coated sample $>140{ }^{\circ} \mathrm{C}$-coated sample, indicating that the corrosion rate of hydrothermal conversion coating samples is slower, and the $140^{\circ} \mathrm{C}$-coated sample has the lowest corrosion rate. Specifically, after corrosion for 6 days, the total mount hydrogen evolution from the $140{ }^{\circ} \mathrm{C}$-coated sample is about $7.4 \mathrm{~mL} \cdot \mathrm{cm}^{-2}$, merely $37 \%$ of that from the cast sample (about $19.8 \mathrm{~mL} \cdot \mathrm{cm}^{-2}$ ). Moreover, all samples have an incubation period in the initial stage of the hydrogen evolution test, which is determined by the erosion process of the corrosive media. In general, the longer the incubation period, the better the corrosion resistance. The observed incubation period is about 1 day for the cast sample and about 2 days in the $140{ }^{\circ} \mathrm{C}$-coated sample.

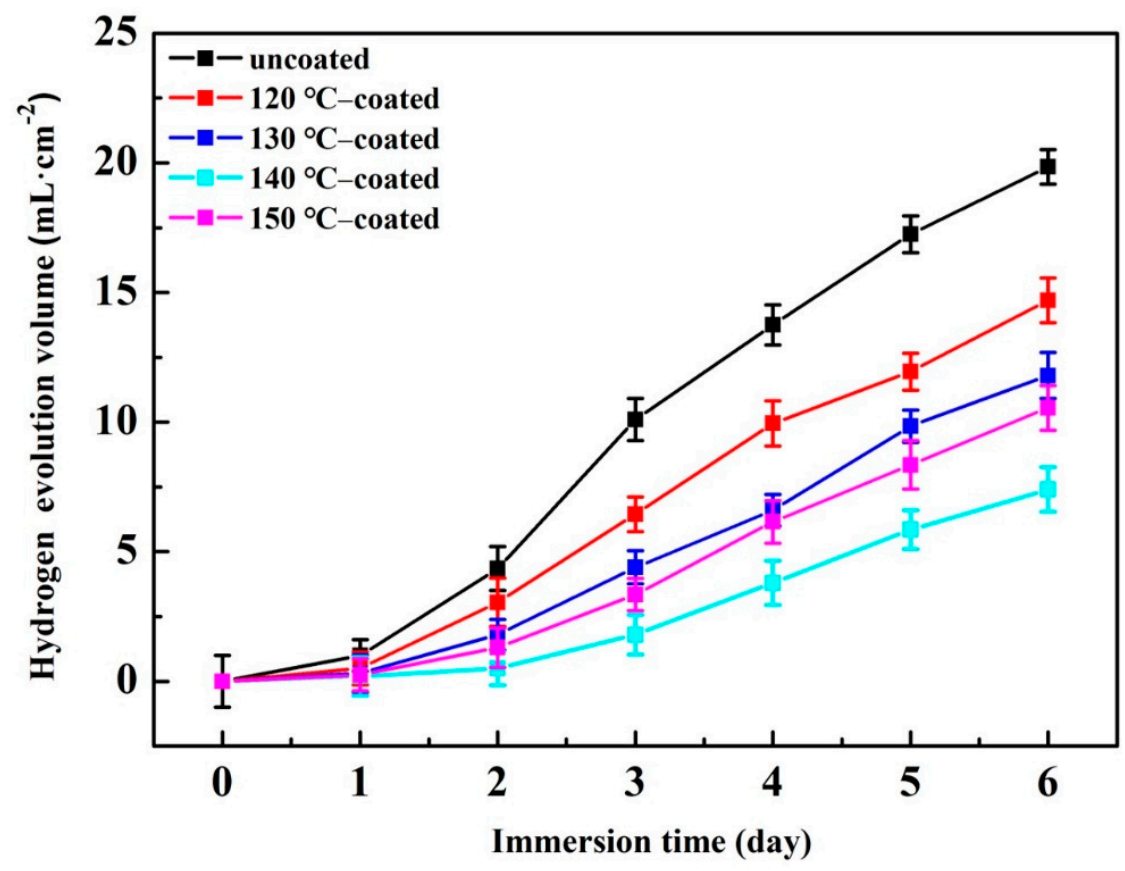

Figure 7. Hydrogen-evolution rates of the substrate and coated samples in $\mathrm{NaCl}$ solution.

The optical and SEM corrosion morphologies of the Mg-9Li substrate and hydrothermally coated samples after hydrogen-evolution immersion in $\mathrm{NaCl}$ solution for six days are shown in Figure 8. The corrosion morphologies of all coated samples demonstrate apparent contrasts in optical observations. Specifically, the uncoated, $120^{\circ} \mathrm{C}, 130{ }^{\circ} \mathrm{C}$, and $150^{\circ} \mathrm{C}$ coated samples have been completely corroded, and the surface shows obvious color difference. However, from the point of view of the corrosion area, the overall corrosion damage of the substrate and coating is alleviated in the $140{ }^{\circ} \mathrm{C}$-coated sample in comparison to other coating samples. 
(a)

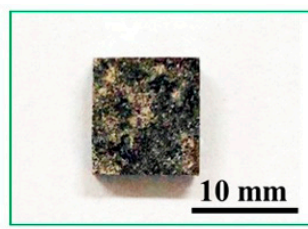

(c)

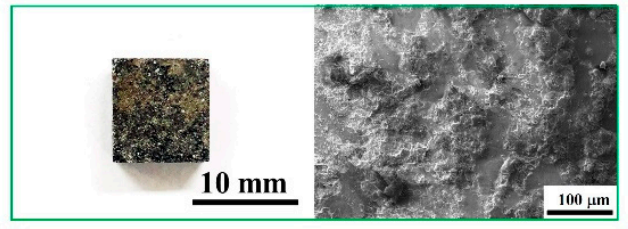

(b)

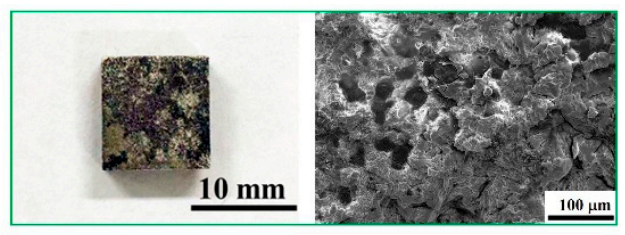

(d)

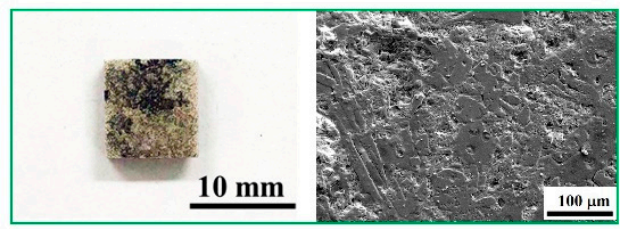

(e)

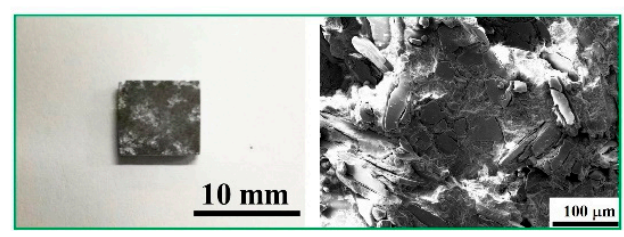

Figure 8. Optical and SEM corrosion morphologies of the cast and coated samples after hydrogen-evolution immersion in $\mathrm{NaCl}$ solution: (a) uncoated sample; (b) $120^{\circ} \mathrm{C}$-coated sample; (c) $130{ }^{\circ} \mathrm{C}$-coated sample; (d) $140{ }^{\circ} \mathrm{C}$-coated sample; (e) $150^{\circ} \mathrm{C}$-coated sample.

The further detailed corrosion morphologies can be seen from SEM images. As seen in Figure 8a, the uncoated sample is severely corroded and there are many stacked corrosion products. The stacked corrosion products layer on the surface of the Mg-9Li alloy is noncompact, which has no blocking effect on the penetration of the corrosive media to the substrate alloy. As for coated samples (Figure 8b,c), the corrosion degree of the coatings is alleviated with the increase of hydrothermal temperatures, and the corrosion products produced by the corrosion reaction on the substrate seep through cracks and stack on the surface, such that the corrosion damage has spread in the depth direction of the substrate. By comparison, as can be seen from Figure $8 \mathrm{~d}$, the coating prepared at $140{ }^{\circ} \mathrm{C}$ maintains a certain degree of integrity and only suffers damage on the surface without spreading in the depth direction, which indicates a compact and uniform coating can provide sufficient protection. It is worth noting that the corrosion morphology of the coating prepared at $150{ }^{\circ} \mathrm{C}$ (Figure 8e) is very different from other samples. The structure of the coating has been completely destroyed due to the chemical corrosion caused by high-temperature hydrothermal treatment and the corrosion damage of the corrosive media. However, it takes a longer time for the corrosive media to penetrate directly into the substrate due to the thicker coating. Thus, the $150{ }^{\circ} \mathrm{C}$-coated sample exhibits slightly higher corrosion resistance in comparison to 120 and $130{ }^{\circ} \mathrm{C}$ coated samples.

\subsection{Adhesion Property}

The adhesion strength between the coating and substrate plays a vital role in corrosion resistance [50]. Figure 9a,b present the macro and SEM images of the $140{ }^{\circ} \mathrm{C}$-coated sample after the scratch test/tape test, respectively, in which it can be clearly seen that none of the squares of the lattice are detached after removing the tape and the edges of the cutting are smooth (shown in Figure 9c). Therefore, the bonding strength of hydrothermal conversion coating on Mg-9Li alloy is 5B according to the classification in ASTM D3359-02 method B. This good bonding force improves the corrosion resistance of the $140{ }^{\circ} \mathrm{C}$-coated sample and protects the substrate from corrosion.

\subsection{Anti-Corrosion Mechanism of Hydrothermal Conversion Coating}

It is generally believed that improvement of the corrosion resistance of the hydrothermalconversion coated sample is determined by two major factors. The first factor is the stability of the coating and its barrier to corrosive media. Furthermore, the corrosion resistance 
of the substrate alloy, as well as the damage of the coating's integrity induced by the corrosion of the substrate alloy, also plays an important role. For all coated samples, the input heat during the hydrothermal reaction process has little effect on the microstructure and corrosion resistance of the as-cast substrate alloy. Therefore, the corrosion behavior and corrosion resistance of the coated samples are mainly determined by the protection effect of the coating, which in turn depends on the hydrophobicity of the coating and the barrier effect on the transmission of the corrosive media.
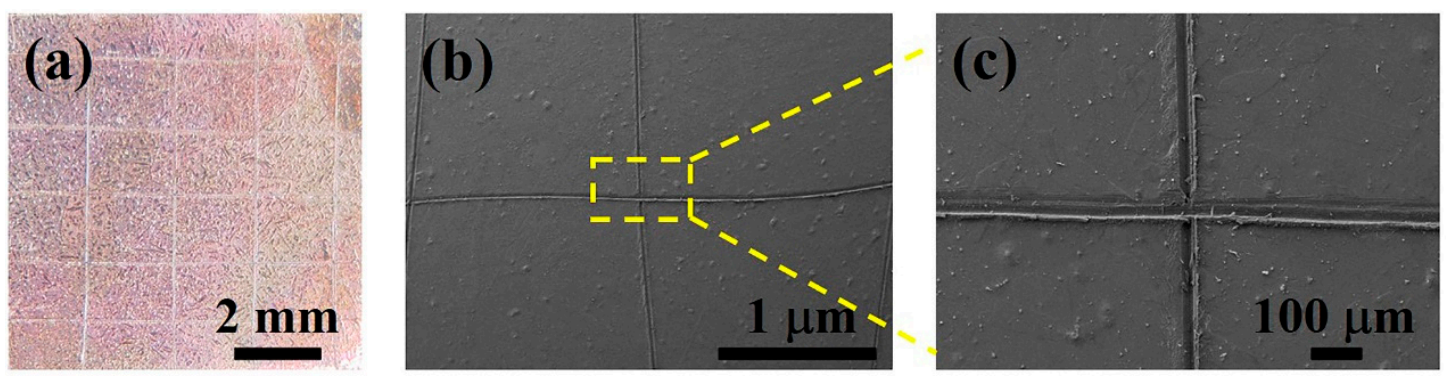

Figure 9. Surface morphology after adhesion test of the $140{ }^{\circ} \mathrm{C}$-coated sample and corresponding partial enlarged image.

As revealed in the surface morphologies (Figure 10) and the cross-sectional morphologies (Figure 4) of the obtained hydrothermal conversion coatings, they all present the special dual-layer structure, which is composed of the external stacking-structure surface layer and internal compact layer. As schematically illustrated in Figure 11a, all the coating surfaces are covered by the stacking structure of the hexagonal flake $\mathrm{Mg}(\mathrm{OH})_{2}$ crystal units. There are a lot of gaps between the stacking-structure units, which can store a certain amount of air, thus providing a certain lifting effect for the droplets and giving the potential hydrophobicity of the coating surface. The static contact angles of the uncoated and coated samples are tested and shown in Figure 11b. The static contact angle of water droplet on the substrate $\mathrm{Mg}-9 \mathrm{Li}$ alloy is only $28.3^{\circ}$. For all coated samples, the contact angle increases first and then drops with the increase of the hydrothermal temperature. It is worth noting that the contact angle of the coated sample fabricated at $140{ }^{\circ} \mathrm{C}$ is the largest, reaching $52.8^{\circ}$. Reports have found that the hexagonal $\mathrm{Mg}(\mathrm{OH})_{2}$ units are stacked on each other to create a rough surface, which is usually beneficial to improve surface wettability [51], effectively preventing the penetration of the corrosive solution into the surface. Generally speaking, the hydrophobic surface can effectively inhibit electrolyte ions from penetrating through the surface of the substrate and thus enhances the corrosion resistance of the coating system [52].

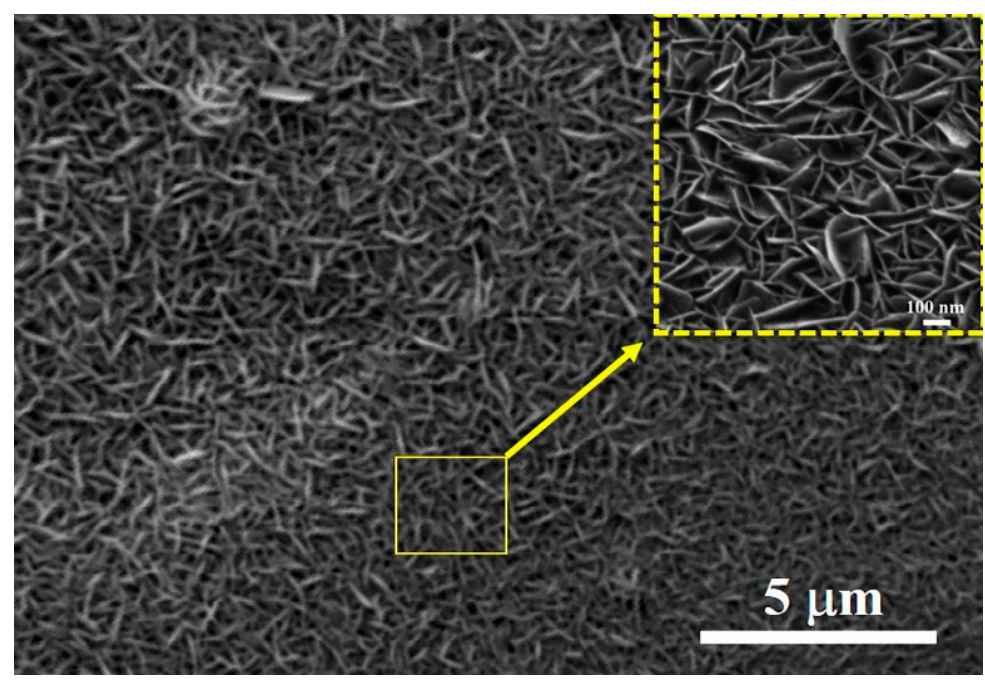

Figure 10. Surface morphologies of hydrothermal conversion coatings. 


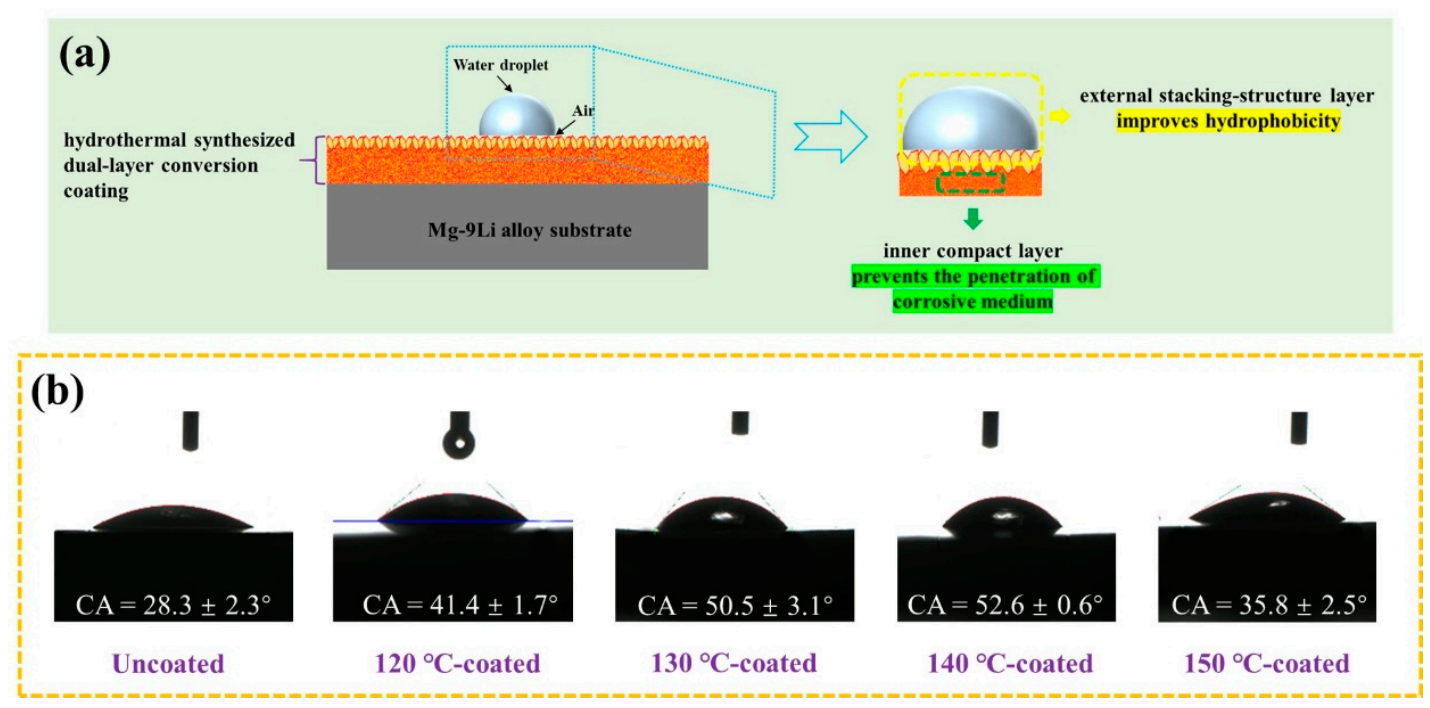

Figure 11. (a) Schematic diagram of hydrothermal conversion coating sample contact with water droplet. (b) The contact angle of the uncoated and coated samples.

The protection of the inner compact and uniform composite coating is also an important factor in the improvement of corrosion resistance. Generally, for the uncoated substrate alloy, the corrosion media will easily penetrate through the surface layer, due to its porous and metastable natureof which is mainly composed of $\mathrm{MgO}$ and magnesium hydroxide hydrate [53-55]. Once the corrosive media reach the substrate, the corrosion damage of the substrate, as well as the corrosion-induced hydrogen evolution will accelerate the degradation of the integrity of the surface layer, leading to the accelerated corrosion of the substrate alloy $[56,57]$. However, as the coated samples, the inner compact coating layer can effectively block the penetration of the corrosive media containing $\mathrm{Cl}^{-}, \mathrm{H}_{2} \mathrm{O}$ and $\mathrm{O}_{2}$, which efficiently retards the direct contact of the corrosive media to the substrate alloy, especially during the initial stage of corrosion. Meanwhile, the thicker and compacter inner coating will provide a better blocking effect against the penetration of the corrosive media, as well as a longer degradation duration of the coating, thus the better corrosion resistance and lower corrosion rate of the coated sample can be achieved.

Judged from the best hydrophobicity of the external surface layer and the uniform and compact inner layer, one can believe that the $140{ }^{\circ} \mathrm{C}$-coated sample has the best corrosion resistance.

\section{Conclusions}

1. The hydrothermal conversion coating synthesized on the Mg-9Li alloy is mainly composed of magnesium hydroxide $\left(\mathrm{Mg}(\mathrm{OH})_{2}\right)$ and a small amount of lithium hydroxide ( $\mathrm{LiOH})$, which present sufficient corrosion prevention performance in $\mathrm{NaCl}$ solution.

2. The coated sample prepared at $140{ }^{\circ} \mathrm{C}$ has a uniform, compact and thick hydrothermal conversion coating. Additionally, the $140^{\circ} \mathrm{C}$-coated sample has the best anti-corrosion performance among the uncoated and coated samples, showing the lowest corrosion current density and hydrogen evolution rate.

3. The hydrothermal conversion coating has a special dual-layer structure which is composed of an external stacking-structure surface layer and inner compact layer.

4. The improvement of the hydrophobicity caused by the stacking structure of the surface layer, as well as the barrier effect of inner compact layer of the hydrothermal conversion coating, endow its excellent corrosion prevention efficiency in the corrosive solution. 
Author Contributions: Writing-review and editing, D.S. and Y.Q.; study design, B.L.; literature search, Y.F.; writing-original draft, G.W.; data analysis, E.E.K. and X.G.; supervision, J.J. All authors have read and agreed to the published version of the manuscript.

Funding: This research was funded by Fundamental Research Funds for the Central Universities of Hohai university (B200202122), National Natural Science Foundation of China (51878246 and 51979099), the Natural Science Foundation of Jiangsu Province of China (BK20191303), Key Research and Development Project of Jiangsu Province of China (BE2017148).

Institutional Review Board Statement: Not applicable.

Informed Consent Statement: Not applicable.

Data Availability Statement: Not applicable.

Acknowledgments: The authors acknowledge the financial support from the Fundamental Research Funds for the Central Universities of Hohai university (B200202122), National Natural Science Foundation of China (51878246 and 51979099), the Natural Science Foundation of Jiangsu Province of China (BK20191303), Key Research and Development Project of Jiangsu Province of China (BE2017148).

Conflicts of Interest: The authors declare no conflict of interest.

\section{References}

1. Wang, T.; Zhang, M.L.; Wu, R.Z. Microstructure and properties of Mg-8Li-1Al-1Ce alloy. Mater. Lett. 2008, 62, 1846-1848. [CrossRef]

2. Xia, Q.X.; Zhang, D.J.; Li, D.Q.; Jiang, Z.H.; Yao, Z.P. Preparation of the plasma electrolytic oxidation coating on Mg-Li alloy and its thermal control performance. Surf. Coat. Technol. 2019, 369, 252-256. [CrossRef]

3. Crawford, P.; Barrosa, R.; Mendez, J.; Foyos, J.; Es-Said, O.S. On the transformation characteristics of LA141A (Mg-Li-Al) alloy. J. Mater. Process. Technol. 1996, 56, 108-118. [CrossRef]

4. Al-Samman, T. Comparative study of the deformation behavior of hexagonal magnesium-lithium alloys and a conventional magnesium AZ31 alloy. Acta Mater. 2009, 57, 2229-2242. [CrossRef]

5. Song, J.M.; Wen, T.X.; Wang, J.Y. Vibration fracture properties of a lightweight Mg-Li-Zn alloy. Scr. Mater. 2007, 56, 529-532. [CrossRef]

6. Maurya, R.; Mittal, D.; Balani, K. Effect of heat-treatment on microstructure, mechanical and tribological properties of Mg-Li-Al based alloy. J. Mater. Res. Technol. 2020, 9, 4749-4762. [CrossRef]

7. Takuda, H.; Kikuchi, S.; Tsukada, T.; Kubota, K.; Hatta, N. Effect of strain rate on deformation behavior of a Mg-8.5Li-1Zn alloy sheet at room temperature. Mater. Sci. Eng. A 1999, 271, 251-256. [CrossRef]

8. Counts, W.A.; Friak, M.; Raabe, D.; Neugebauer, J. Using ab initio calculations in designing bcc Mg-Li alloys for ultra-lightweight applications. Acta Mater. 2009, 57, 69-76. [CrossRef]

9. Rahmatabadi, D.; Pahlavani, M.; Gholami, M.D.; Marzbanrad, J.; Hashemi, R. Production of Al/Mg-Li composite by the accumulative roll bonding process. J. Mater. Res. Technol. 2020, 9, 7880-7886. [CrossRef]

10. Xu, D.K.; Han, E.H. Effect of quasicrystalline phase on improving the corrosion resistance of a duplex structured Mg-Li alloy. Scr. Mater. 2014, 71, 21-24. [CrossRef]

11. Hung, S.M.; Lin, H.; Chen, H.W.; Chen, S.Y.; Lin, C.S. Corrosion resistance and electrical contact resistance of a thin permanganate conversion coating on dual-phase LZ91 Mg-Li alloy. J. Mater. Res. Technol. 2021, 11, 1953-1968. [CrossRef]

12. Zhang, C.H.; Huang, X.M.; Zhang, M.L.; Gao, L.L.; Wu, R.Z. Electrochemical characterization of the corrosion of a Mg-Li Alloy. Mater. Lett. 2008, 62, 2177-2180. [CrossRef]

13. Gao, L.L.; Zhang, C.H.; Zhang, M.L.; Huang, X.M.; Sheng, N. The corrosion of a novel Mg-11Li-3Al-0.5RE alloy in alkaline NaCl solution. J. Alloys Compd. 2009, 468, 285-289. [CrossRef]

14. Gray, J.E.; Luan, B. Protective coatings on magnesium and its alloys-A critical review. J. Alloys Compd. 2002, 336, 88-113. [CrossRef]

15. Chang, L.M.; Wang, P.; Liu, W. Effect of Amino Acids on the Structure and Corrosion Resistance of Mg-Li Alloy Anodic Oxide Film. Adv. Mater. Res. 2011, 1030, 785-788. [CrossRef]

16. Li, J.F.; Zheng, Z.Q.; Li, S.C.; Ren, W.D.; Zhang, Z. Preparation and galvanic anodizing of a Mg-Li alloy. Mater. Sci. Eng. A 2006, 433, 233-240. [CrossRef]

17. Yamauchi, N.; Ueda, N.; Okamoto, A.; Sone, T.; Tsujikawa, M.; Oki, S. DLC coating on Mg-Li alloy. Surf. Coat. Technol. 2007, 210, 4913-4918. [CrossRef]

18. Yin, Z.Z.; Qi, W.C.; Zeng, R.C.; Chen, X.B.; Gu, C.D.; Guan, S.K.; Zheng, Y.F. Advances in coatings on biodegradable magnesium alloys. J. Magnes. Alloys 2020, 8, 42-65. [CrossRef]

19. Yang, L.H.; Li, J.Q.; Zheng, Y.Z.; Jiang, W.W.; Zhang, M.L. Electroless Ni-P plating with molybdate pretreatment on Mg-8Li alloy. J. Alloys Compd. 2009, 467, 562-566. [CrossRef] 
20. Yang, L.H.; Zhang, M.L.; Li, J.Q.; Yu, X.; Niu, Z.Y. Stannate conversion coatings on Mg-8Li alloy. J. Alloys Compd. 2009, 471, 197-200. [CrossRef]

21. Zhang, H.; Yao, G.C.; Wang, S.L.; Liu, Y.H.; Luo, H.J. A chrome-free conversion coating for magnesium-lithium alloy by a phosphate-permanganate solution. Surf. Coat. Technol. 2008, 202, 1825-1830. [CrossRef]

22. Shao, Y.W.; Huang, H.; Zhang, T.; Meng, G.Z.; Wang, F.H. Corrosion protection of Mg-5Li alloy with epoxy coatings containing polyaniline. Corros. Sci. 2009, 51, 2906-2915. [CrossRef]

23. Oki, S.; Tsujikawa, M.; Morishige, T.; Kamita, M. Thin Protective Aluminum Layer on Mg-Li Alloy by Plasma Spraying and Cold Rolling. Plasma. Process. Polym. 2009, 6, S954-S957. [CrossRef]

24. Yang, C.L.; Xue, D.F.; Zou, L.J.; Yan, X.X.; Wang, W. Preparation of magnesium hydroxide nanoflowers. J. Cryst. Growth 2005, 282, $448-454$

25. Guo, G.H.; Song, D.; Jiang, J.H.; Ma, A.B.; Zhang, L.W.; Li, C. Effect of Synthesizing Temperature on Microstructure and Electrochemical Property of the Hydrothermal Conversion Coating on Mg-2Zn-0.5Mn-Ca-Ce Alloy. Metals 2016, 6, 44. [CrossRef]

26. Zhu, Y.Y.; Wu, G.M.; Zhang, Y.H.; Zhao, Q. Growth and characterization of $\mathrm{Mg}(\mathrm{OH})_{2}$ film on magnesium alloy AZ31. Appl. Surf. Sci. 2011, 257, 6129-6137. [CrossRef]

27. Gupta, R.K.; Mensah-Darkwa, K.; Kumar, D. Corrosion Protective Conversion Coatings on Magnesium Disks Using a Hydrothermal Technique. J. Mater. Sci. Technol. 2014, 30, 47-53. [CrossRef]

28. Feng, L.B.; Zhu, Y.L.; Wang, J.; Shi, X.T. One-step hydrothermal process to fabricate superhydrophobic surface on magnesium alloy with enhanced corrosion resistance and self-cleaning performance. Appl. Surf. Sci. 2017, 422, 566-573. [CrossRef]

29. Wang, Z.W.; Su, Y.L.; Li, Q.; Liu, Y.; She, Z.X.; Chen, F.N.; Li, L.Q.; Zhang, X.X.; Zhang, P. Researching a highly anti-corrosion superhydrophobic film fabricated on AZ91D magnesium alloy and its anti-bacteria adhesion effect. Mater. Charact. 2015, 99, 200-209. [CrossRef]

30. ASTM D 3359-02: Standard Test Methods for Measuring Adhesion by Tape Test; ASTM: Philadelphia, PA, USA, 2002.

31. Wang, G.W.; Song, D.; Li, C.; Klu, E.E.; Qiao, Y.X.; Sun, J.P.; Jiang, J.H.; Ma, A.B. Developing Improved Mechanical Property and Corrosion Resistance of Mg-9Li Alloy via Solid-Solution Treatment. Metals 2019, 9, 920. [CrossRef]

32. Song, Y.W.; Shan, D.Y.; Chen, R.S.; Han, E.H. Corrosion characterization of Mg-8Li alloy in NaCl solution. Corros. Sci. 2009, 51, 1087-1094. [CrossRef]

33. Ling, L.; Cai, S.; Li, Q.Q.; Sun, J.Y.; Bao, X.G.; Xu, G.H. Recent advances in hydrothermal modification of calcium phosphorus coating on magnesium alloy. J. Magnes. Alloys 2021. [CrossRef]

34. Kaabi Falahieh Asl, S.; Nemeth, S.; Tan, M.J. Mechanism of calcium phosphate deposition in a hydrothermal coating process. Surf. Coat. Technol. 2015, 270, 197-205. [CrossRef]

35. Wang, G.W.; Song, D.; Zhou, Z.Z.; Klu, E.E.; Liu, Y.; Liang, N.N.; Jiang, J.H.; Sun, J.P.; Ma, A.B. Effect of Ultrafine Grains on the Coating Reaction and Anticorrosion Performance of Anodized Pure Aluminum. Coatings 2020, 10, 216. [CrossRef]

36. Li, Z.; Peng, Z.Y.; Qiu, Y.B.; Qi, K.; Chen, Z.Y.; Guo, X.P. Study on heat treatment to improve the microstructure and corrosion behavior of ZK60 magnesium alloy. J. Mater. Res. Technol. 2020, 9, 11201-11219. [CrossRef]

37. Kuang, J.; Ba, Z.X.; Li, Z.Z.; Wang, Z.Z.; Qiu, J.H. The study on corrosion resistance of superhydrophobic coatings on magnesium. Appl. Surf. Sci. 2020, 501, 144137. [CrossRef]

38. Lou, B.S.; Yen, C.Y.; Chen, Y.Y.; Lee, J.W. Effects of processing parameters on the adhesion and corrosion resistance of oxide coatings grown by plasma electrolytic oxidation on AZ31 magnesium alloys. J. Mater. Res. Technol. 2021, 10, 1355-1371. [CrossRef]

39. Wang, Z.B.; Hu, H.X.; Zheng, Y.G.; Ke, W.; Qiao, Y.X. Comparison of the corrosion behavior of pure titanium and its alloys in fluoride-containing sulfuric acid. Corros. Sci. 2016, 103, 50-65. [CrossRef]

40. Qiao, Y.X.; Xu, D.K.; Wang, S.; Ma, Y.J.; Chen, J.; Wang, Y.X.; Zhou, H.L. Effect of hydrogen charging on microstructural evolution and corrosion behavior of a Ti-4Al-2V-1Mo-1Fe alloy. J. Mater. Sci. Technol. 2021, 60, 168-176. [CrossRef]

41. Song, D.; Li, C.; Liang, N.N.; Yang, F.L.; Jiang, J.H.; Sun, J.P.; Wu, G.S.; Ma, A.B.; Ma, X.L. Simultaneously improving corrosion resistance and mechanical properties of a magnesium alloy via equal-channel angular pressing and post water annealing. Mater. Des. 2019, 166, 107621. [CrossRef]

42. Zhang, Z.Q.; Wang, L.; Zeng, M.Q.; Zeng, R.C.; Lin, C.G.; Wang, Z.L.; Chen, D.C.; Zhang, Q. Corrosion resistance and superhydrophobicity of one-step polypropylene coating on anodized AZ31 Mg alloy. J. Magnes. Alloys 2021, 9, $1443-1457$. [CrossRef]

43. Baril, G.; Pebere, N. The corrosion of pure magnesium in aerated and deaerated sodium sulphate solutions. Corros. Sci. 2001, 43, 471-484. [CrossRef]

44. Baril, G.; Blanc, C.; Pebere, N. AC impedance spectroscopy in characterizing time-dependent corrosion of AZ91 and AM50 magnesium alloys-Characterization with respect to their microstructures. J. Electrochem. Soc. 2001, 148, B489-B496. [CrossRef]

45. Bonora, P.L.; Andrei, M.; Eliezer, A.; Gutman, E.M. Corrosion behaviour of stressed magnesium alloys. Corros. Sci. 2002, 44, 729-749. [CrossRef]

46. Zhang, J.Q.; Cao, C.N. Introduction of Electrochemical Impedance Spectroscopy; Science Press: Beijing, China, 2002.

47. Wu, H.; Shi, Z.; Zhang, X.M.; Qasim, A.M.; Xiao, S.; Zhang, F.; Wu, Z.Z.; Wu, G.S.; Ding, K.J.; Chu, P.K. Achieving an acid resistant surface on magnesium alloy via bio-inspired design. Appl. Surf. Sci. 2019, 478, 150-161. [CrossRef]

48. Gan, W.; Liu, C.F.; Lu, F.Q. Study on surface modification and properties of the AZ91D magnesium alloy used for automobile engine. J. Mater. Res. Technol. 2020. [CrossRef] 
49. Qiao, Y.X.; Chen, Y.P.; Li, L.L.; Emori, W.; Chen, J.; Wang, X.J.; Yang, L.L.; Zhou, H.L.; Song, G.; Naik, N.; et al. Corrosion behavior of a nickel-free high-nitrogen stainless steel with hydrogen charging. JOM 2021, 73, 1165-1172. [CrossRef]

50. Zhou, H.L.; Li, J.Y.; Li, J.; Ruan, Q.D.; Peng, X.; Li, S.J.; Jin, W.H.; Yu, Z.T.; Chu, P.K.; Li, W. A composite coating with physical interlocking and chemical bonding on WE43 magnesium alloy for corrosion protection and cytocompatibility enhancement. Surf. Coat. Technol. 2021, 412, 127078. [CrossRef]

51. Ishizaki, T.; Sakamoto, M. Facile Formation of Biomimetic Color-Tuned Superhydrophobic Magnesium Alloy with Corrosion Resistance. Langmuir 2011, 27, 2375-2381. [CrossRef]

52. Li, W.; Kang, Z.X. Fabrication of corrosion resistant superhydrophobic surface with self-cleaning property on magnesium alloy and its mechanical stability. Surf. Coat. Technol. 2014, 253, 205-213. [CrossRef]

53. Song, D.; Ma, A.B.; Jiang, J.H.; Lin, P.H.; Yang, D.H.; Fan, J.F. Corrosion behavior of equal-channel-angular-pressed pure magnesium in $\mathrm{NaCl}$ aqueous solution. Corros. Sci. 2010, 52, 481-490. [CrossRef]

54. Song, D.; Ma, A.B.; Jiang, J.H.; Lin, P.H.; Yang, D.H.; Fan, J.F. Corrosion behaviour of bulk ultra-fine grained AZ91D magnesium alloy fabricated by equal-channel angular pressing. Corros. Sci. 2011, 53, 362-373. [CrossRef]

55. Liu, H.G.; Cao, F.Y.; Song, G.L.; Zheng, D.J.; Shi, Z.M.; Dargusch, M.S.; Atrens, A. Review of the atmospheric corrosion of magnesium alloys. J. Mater. Sci. Technol. 2019, 35, 2003-2016. [CrossRef]

56. Esmaily, M.; Svensson, J.E.; Fajardo, S.; Birbilis, N.; Frankel, G.S.; Virtanen, S.; Arrabal, R.; Thomas, S.; Johansson, L.G. Fundamentals and advances in magnesium alloy corrosion. Prog. Mater. Sci. 2017, 89, 92-193. [CrossRef]

57. Zhang, D.D.; Peng, F.; Liu, X.Y. Protection of magnesium alloys: From physical barrier coating to smart self-healing coating. J. Alloys Compd. 2021, 853, 157010. [CrossRef] 